\title{
Rip current occurrence probability at selected recreational beaches along Pahang coastline
}

\author{
Muhammad Amirul Syafiq Hamsan \\ Department of Marine Science, Kulliyyah of Science, \\ International Islamic University Malaysia, Kuantan, Malaysia, and \\ Muhammad Zahir Ramli \\ Institute of Oceanography and Maritime Studies (INOCEM), \\ International Islamic University Malaysia, Kuantan, Malaysia
}

Rip current occurrence probability

Received 14 January 2020 Revised 2 March 2020 Accepted 8 March 2020

\begin{abstract}
Purpose - Pahang beaches draw more than thousand visitors throughout the year. From the year 2006 to 2018, more than 30 drowning and near-drowning cases were recorded mainly from rip currents. Rip currents are defined as unexpected currents that carried beachgoers away to seaward direction more than approximately $50 \mathrm{~m}$ from shore. The prediction of rip current development is very important for the protection of human life. This study aims to conduct preliminary survey and field works to identify rip current hazards.

Design/methodology/approach - The output would be an early warning preventative mitigation to public in Pahang. Beach state model, dimensionless fall velocity, littoral environment observation and relative tidal range were recorded for five recreational beaches during two different months (March and April 2018). The morphodynamic parameters such sediment fall velocity, sediment grain size and beach slope are then analysed using software PROFILER. Classification of risks was done based on beach morphodynamic model. The morphodynamics are classified as low tide bar rip, barred and low tide terrace associated with rip current, bar dissipative, reflective, non-bar dissipative, low tide terrace and ultra-dissipative.

Findings - Result shows three out of five recreational beaches may develop high-risk rip currents. During the first month of the survey, Batu Hitam $(\mathrm{BH})$ was recorded the only one recreational beach that may develop high-risk rip current followed by Teluk Cempedak (TC) and Kempadang (KEM) as middle-risk rip current beaches, while Balok (BA) and Sepat (SEP) as low-risk rip current beaches. Different during second month of the survey, BA, BH and SEP were recorded as high-risk rip current beaches while TC and KEM as low-risk rip current beaches.
\end{abstract}

Originality/value - The results are consistent with beach incidents (drowning and near-drowning) reported.

Keywords Beach morphodynamic model, Pahang recreational beach, Rip currents,

Sediment fall velocity, Sediment grain size

Paper type Research paper

(C) Muhammad Amirul Syafiq Hamsan and Muhammad Zahir Ramli. Published in Ecofeminism and Climate Change. Published by Emerald Publishing Limited. This article is published under the Creative Commons Attribution (CC BY 4.0) licence. Anyone may reproduce, distribute, translate and create derivative works of this article (for both commercial and non-commercial purposes), subject to full attribution to the original publication and authors. The full terms of this licence may be seen at http://creativecommons.org/licences/by/4.0/legalcode

This work was funded by the Ministry of Higher Education (MOHE) of Malaysia under the Fundamental Research Grant Scheme (FRGS) No. FRGS17-042-0608.

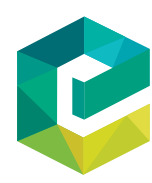

Ecofeminism and Climate Change Vol. 1 No. 1,2020 pp. $37-50$ p-ISSN: 2633-4062 p-ISSN: $2633-4062$ DOI 10.1108/EFCC-03-2020-0005 
EFCC

1,1

\section{Introduction}

Beaches are potentially hazardous to people as beach goers, swimmers and bathers enter the surf zone that is considered as a no man's land in many coastal countries that need to be avoided at all cost. However, with increasing attractive locations for tourism, residential and recreational development, this safety and precaution has been slowly neglected.

Beach hazard is among the element of the coastal environment that exposes public to harm and hazardous events. According to Short and Hogan (1994), hazards could be any phenomena or event that threats people life and their activity. Every beach has specific physical characteristics in contributing to the harmful hazard to public. Short and Hogan (1994) have listed those five physical characteristics as: water depth, surf zone and beach topography, surf zone current, breaking wave and local hazard such as tidal current, reef structure, offshore wind and rocky shore platform.

Rip currents are the greatest beach hazard that occurs at the surf zone. These currents are natural phenomena influence by tide, wind, wave and beach morphology that only happen at sandy beaches surf zone (Castella et al., 2013) with combination of its speed and pattern of circulation (Scott et al., 2014). Rip current was firstly named by Shepard (1936) and described as strong, jet-like and narrow current that flow seaward from surf zone that extend beyond to point of breaking wave. This harmful situation mostly occurs in surf zone with natural beach and rip channel (Bruneau et al., 2011; Kim et al., 2016) that bring swimmer and bather away from the beach in seaward direction which leads to drowning. Rip current has not only become a threat to the safety of beach goers and swimmers but it has also become one of the factors for shoreline changes which transports sediments to offshore (Loureiro et al., 2012; Castella et al., 2015).

\section{Materials and method}

\subsection{Description of study area}

The study area are comprises five recreational beaches in Pahang from Balok (BA) $\left(3^{\circ} 55^{\prime} 25.76^{\prime \prime} \mathrm{N}, 103^{\circ} 22^{\prime} 24.82^{\prime} \mathrm{E}\right)$ located at northern part of the state to Sepat (SEP) $\left(3^{\circ} 41^{\prime} 47.21^{\prime \prime} \mathrm{N}, 103^{\circ} 20^{\prime} 21.37^{\prime \prime} \mathrm{E}\right)$ where it is located at the southern region of the Kuantan district of the state, as shown in Figure 1. The coastline of study area is located at the east coast peninsular Malaysia facing the South China Sea. The coastline is fully exposed and vulnerable with attacks of wave and wind from South China Sea. The meteorological climate of Pahang is most influenced by two monsoons, namely, northeast monsoon (November to March) known as wet season and southwest monsoon (May to September) known as dry season and two shorter inter-monsoons (October and April). The annual rainfall is $2,400 \mathrm{~mm} /$ year with average temperature of $28^{\circ} \mathrm{C}$. The highest and lowest rainfall intensity is focused on December and January, respectively, and the average wind speed is $5 \mathrm{mph}$ with the relative humidity of $85 \%$ (Tukimat et al., 2018). Generally, the coastline consists two types of morphology shoreline backgrounds, i.e. rocky shore (Teluk Cempedak [TC] and Batu Hitam [BH]) and sandy shore (BA, Kempadang [KEM] and SEP). According to Mustapa et al. (2015), the geomorphology characteristics along the coastal area consist of sandy and muddy beaches with total length of $209 \mathrm{~km}$ of Pahang coastline. This study identified five recreational beaches along the South China Sea, namely, BA, BH, TC, KEM and SEP. Coordinates (latitude and longitude) for each station were recorded using Garmin 62S Global Positioning System (GPS). All the coordinates are tabulated in Table 1. 


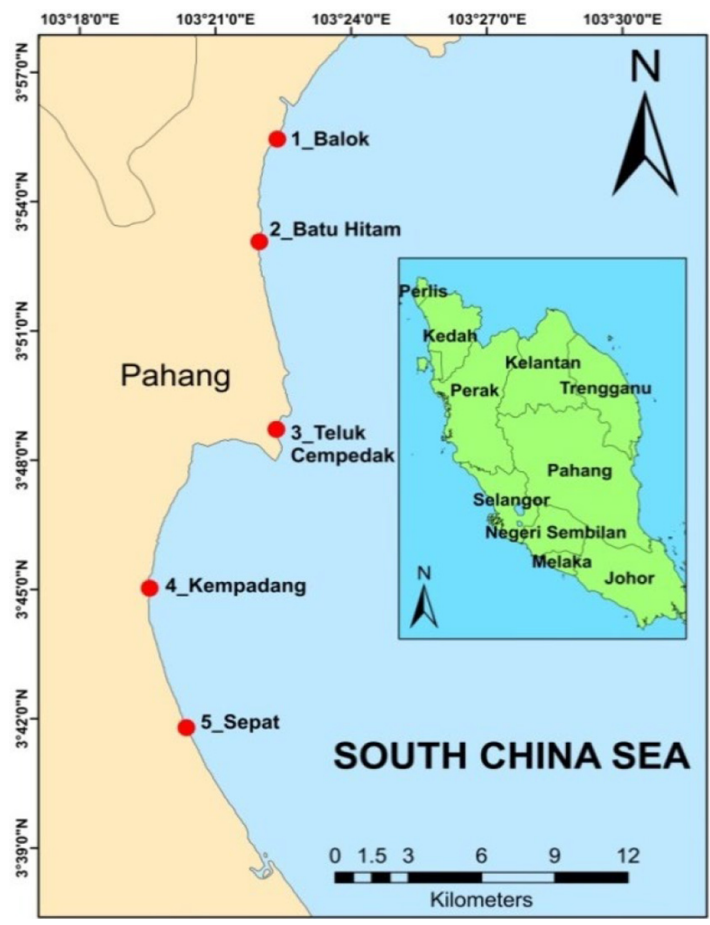

Rip current occurrence probability

Figure 1. Study area which consists of five beaches

GPS coordinates Latitude $(\mathrm{N})$

$3^{\circ} 55.440$,

$3^{\circ} 53.100$,

$3^{\circ} 48.720$ '

$3^{\circ} 45.060^{\prime}$

$3^{\circ} 41.820^{\prime}$
Longitude (E)

$103^{\circ} 22.380^{\prime}$

$103^{\circ} 21.960$,

$103^{\circ} 22.320^{\prime}$

$103^{\circ} 19.560$ '

$103^{\circ} 20.340^{\prime}$
Location

BA

$\mathrm{BH}$

TC

KEM

SEP
Table 1.

GPS coordinates for the location of the study area BA to SEP

\section{Data collection}

\subsection{Drowning cases from 2006 to 2018}

The fatalities drowning record event were examined to classify potential rip current fatalities at recreational beaches along Pahang coastline during the period 2006-2018. As mentioned earlier, Figure 1 shows the study location and it is place within Pahang coastline region. The data contain the drowning recorded only in Kuantan district region of Pahang. The drowning reports are made for both death and non-fatal drowning as shown in Table 2.

Basically, the data were collected from various reliable sources such Fire and Rescue Department, Malaysia Civil Defence Force and online newspapers that reported drowning incidents at Pahang beaches. Data from Fire and Rescue Department and Malaysia Civil Defence Force were restricted to the most recent years of data compilation from year 2012 to 2017 and year 2014 to 2016, respectively. Online newspapers drowning reported were 


\section{EFCC 1,1}

\begin{tabular}{lll}
\hline Date $(\mathrm{dd} / \mathrm{mm} / \mathrm{yyyy})$ & Accident & Reference \\
\hline $31 / 1 / 2006$ & 3 deaths & Utusan Malaysia (2006) \\
$25 / 1 / 2009$ & 2 deaths & Utusan Malaysia (2009) \\
$27 / 1 / 2009$ & 1 death & Fire and Rescue \\
& & Department of Malaysia \\
& & $(2018)$
\end{tabular}

01/01/2012-30/01/2012

01/01/2014-31/12/2014

$17 / 3 / 2015$

01/01/2016-31/12/2016

\section{Table 2.}

Drowning accidents reported during 2006-2018 along Pahang coastline

$2 / 1 / 2017$

01/01/2018-31/12/2018
Jan 1st, 2 deaths Jan 22nd, 2 deaths and 1 rescue

Jan 23rd, 1 death

Apr 24th, 3 deaths Aug 2nd, 1 death Sept 15th, 1 death Sept 29th, 1 death Oct 15th, 1 death

1 death
Jan 3 rd, 1 death

Feb 21st, 1 death

Nov 30th, 1 death

1 drowning

Jun 16th, 3 rescues

Aug 10th, 2 deaths and 2 rescues
Kosmo (2012)

Utusan Malaysia (2012a, 2012b)

Fire and Rescue Department of Malaysia (2018)

Bernama (2014a)

Bernama (2014b)

N.A (2014)

Fire and Rescue Department of Malaysia (2018)

N.A (2017)

Alagesh (2018)

Berita Harian (2018)

collected from 2006 to 2018 . The data from these three sources were first checked, corrected and aligned with online newspapers for any errors, anomalies and repetitive data. In this data, only drowning and rescue numbers were given that does not include the primary cause of drowning and the area along the beach where drowning occurred. These data were specifically collected to relate and examine the drowning accident that might associate with rip current hazard.

\subsection{Sediment analysis}

A total of 30 sand samples were collected at 5 sandy beaches in 2 different sampling campaigns (March and April 2018). Samples were taken at cross-shore elevation in the transect perpendicular to the shore at different tidal zone (high tide, middle tide and low tide). Dry sieve method was used in this study to give an insight about sediment grain size. Samples were dried for $24 \mathrm{~h}$ in an oven at range temperature between $60^{\circ} \mathrm{C}$ and $70^{\circ} \mathrm{C}$ as described in Rosnan and Zaini (2010). In this study, the dry sieve method is chosen because only sediments with grain size $>63 \mu \mathrm{m}$ were obtained.

Dry sieve method was performed using a series of sieves in different ranges of size from 0.063 to $4.0 \mathrm{~mm}(0.063,0.09,0.125,0.18,0.25,0.355,0.5,0.71,1.0,1.4,2.0,2.8$ and 4.0$)$ along with mechanical sieve shaker. First, $200 \mathrm{~g}$ of each sediment sample was sieved for about 10 $15 \mathrm{~min}$. Sediment samples that retained at each mesh were weighted using electronic balance. 
Further analysis was done using computer software named GRADISTAT package (Blott and Pye, 2001) to calculate the analytical statistic parameter for grain size distribution (mean grain size diameter). From this analysis, we also have a good understanding of sediment fall velocity values that can be predicted by Gibbs equation using $\mathrm{D}_{50}$ sieve size and empirical sand density.

\subsection{Beach slope}

Beach profile were conducted in two different surveys. A consecutive four days between 14th March to 10th April 2018 and three days between 24th April to 26 April 2018. The beaches were covered $400 \mathrm{~m}$ by up to 20 transects with $20 \mathrm{~m}$ between the line transects. The interval within transects is set irregular based on the different changes of morphology. The beach profile is taken from vegetative area to low-tide mark using Theodolite Total Station instrument (Leica Builder 409). The beach profile is used to obtained slope value using Profiler 3.2 XL software (Cohen, 2016).

\subsection{Beach state classification}

To determine the beach state for rip current hazard assessment, Wright and Short (1984) introduced beach state morphodynamic model, which is dimensionless fall velocity $(\Omega)$ earlier proposed by Dean (1973) and Gourlay (1968).The model defined dimensionless fall velocity $(\Omega)$ parameters as:

$$
\Omega=\mathrm{H}_{\mathrm{b}} / \mathrm{TW}_{\mathrm{s}}
$$

where $\mathrm{H}_{\mathrm{b}}$ is wave breaking height (m), $T$ is wave period (s) and $\mathrm{W}_{\mathrm{s}}$ is sediment fall velocity $(\mathrm{m} / \mathrm{s})$. In this beach morphodynamic model, the beach states are divided into three types named: reflective $(\Omega<1)$, intermediate $(1<\Omega<6)$ and dissipative $(\Omega>6)$. To calculate the dimensionless fall velocity $(\Omega)$, the breaking wave height $\left(\mathrm{H}_{\mathrm{b}}\right)$ and wave period $(\mathrm{T})$ are taken previously from littoral environment observation (LEO).

By taking action from tidal range impact, later the tidal range parameters (relative tidal range [RTR]) proposed by Masselink and Short (1993) were taken into calculation as:

$$
\mathrm{RTR}=\mathrm{TR} / \mathrm{H}_{\mathrm{b}}
$$

where TR is mean spring tide range (m).

By using both $\Omega$ and RTR parameters, the beach classifications are divided into four groups and eight types. The groups and types of the beach are described as follows.

\subsection{Reflective group}

This group usually have $\Omega<2$ and RTR $<7$. For RTR $<3$, the beach characterizes as fully reflective $(R)$ beach type. This beach type has steep and cuspate structure at the beach face. The wave characterises normally as surging or plunging as described in Huntley and Bowen (1975) and Wright and Short (1984).

This group also belong to RTR between 3 and 7 and $\Omega<2$. The beach type is low tide terrace associated with rip current structure (LTTR). Usually this beach type has steep beach face and looks like reflective beach during high tide and flat beach structure during low tide.

When RTR $>7$, the beach tends to be more wide and dissipative with low tide terrace without rip current channel characteristics. 
EFCC

1,1

3.6 Intermediate group

For this group, $\Omega$ is between 2 and 5 while RTR $<7$. RTR $<3$ is classifying as barred (B) topography beach type with several bar appeared. For RTR between 3 and 7 , the beach classifying as low tide bar rip (LTBR) beach type. This beach characterise as steep at the upper part until mid-part (intertidal zone) and rip morphology such as sand bar and channel at low tide level. The rip morphology only exists when approaching low tide.

3.7 Dissipative group

In this group, $\Omega>5$ and RTR $<7$. RTR $<3$ characterises as barred dissipative (BD) beach. This is impact from long-shore current that forms bar-trough morphology. As RTR increases more than 3 , the beaches tend to become non-barred dissipative (NBD) beach with flat and no bar features.

\subsection{Ultra-dissipative group}

This group of beach usually has $\Omega>2$ and RTR $>7$ and is named as ultra-dissipative beach. General beach morphology is wide and flat intertidal zone.

For sediment fall velocity $\left(\mathrm{W}_{\mathrm{s}}\right)$ is calculated using equation as:

$$
\mathrm{W}_{\mathrm{s}}=\left(\operatorname{RgD}^{2}\right) /\left[\mathrm{C}_{1} \boldsymbol{v}+\left(\begin{array}{ll}
0.75 & \mathrm{C}_{2} \operatorname{RgD}{ }^{3}
\end{array}\right)^{0.5}\right.
$$

where $\mathrm{R}$ is submerged specific gravity (1.65 for quartz in water), D is sediment grain size, $\mathrm{D}_{50}(\mathrm{~m}), v$ is the kinematic viscosity of fluid $\left(v=1.0 \times 10^{-6} \mathrm{~kg} \mathrm{~m}^{-1} \mathrm{~s}^{-1}\right)$ and $\mathrm{C} 1$ and $\mathrm{C} 2$ are constant as they are likely opposite extreme for angular natural grains and as suggested by Ferguson and Church (2004), $\mathrm{C}_{1}=24$ and $\mathrm{C}_{2}=1.2$.

In this study, the type breaker is estimated using surf similarity $\left(\xi_{\mathrm{b}}\right)$ as in equation (3):

$$
\xi_{b}=\tan \beta /\left(\mathrm{H}_{b} / L_{0}\right)^{0.5}
$$

where $\tan \beta$ is a beach slope and $\mathrm{L}_{0}$ is wave length that is calculated as in equation (4):

$$
L_{0}=g T^{2} / 2 \pi
$$

where $g$ is gravitational constant $\left(9.810 \mathrm{~m} / \mathrm{s}^{2}\right), T$ is wave period (s) and $\Pi$ is constant value (3.142). This surf similarity estimated three different breakers: spilling breaker $\left(\xi_{\mathrm{b}}<0.4\right)$, plunging breaker $\left(0.4<\xi_{\mathrm{b}}<2\right)$ and surging breaker $\left(\xi_{\mathrm{b}}>2\right)$ (Battjes, 1974; Galvin, 1968).

\section{Result and discussion}

In this chapter, the outcomes are presented in two sections:

(1) drowning fatalities associated rip currents; and

(2) beach morphodynamic state.

The characteristic of wave collected observation data (LEO) contains slightly important parameters such as significant wave height, breaker wave height and wave period to determine the beach morphodynamic state. Apart from that, sediment grain size $\left(\mathrm{D}_{50}\right)$ also is basic essential in determining the beach state. 
To classify the beach state that associated is with rip current, the short-term data within two months for beach morphodynamic on BA, BH, TC, KEM and SEP were analysed as follows:

- beach gradient; and

Rip current occurrence probability

- beach state classification as well as type breaker.

In determining the behaviour of drowning cases at recreational beaches related to rip currents, the drowning incident were analysed as drowning (fatal), drowning (fatal/nonfatal/rescue) and rescue. General suggestion for the collecting drowning data is briefly discussed.

\subsection{Drowning-related rip current rescues and fatalities}

In this study, the primary sources of these drowning data are from media reports with more input from online newspapers rather than emergency management and water rescue official teams report. These drowning data have their own limitation because of unreported and undocumented primary cause of drowning. This will lead to difficulties of tracking down the drowning cases and accidents because of rip currents hazard. This is the worldwide problem to get the real significant drowning data from this event. Brington et al. (2013) suggested that collecting drowning data information such as primary causes of fatalities or rescue and where the drowning happen at the beach is significantly important to allow more accurate determination and study the impact of rip currents hazard affecting the drowning and rescue numbers. From that suggestion, it can help beach practitioners to highlight public awareness and beach safety strategies efficiently.

Table 2 shows the drowning cases as function of location and gives an insight of the high and low frequency of drowning that occurred along Pahang coastline when compared with other beach stretch which had relatively zero accidents. Examination of drowning event data gives total number of 31 incidents during the period 2006-2018; including both fatal and hospitalise non-fatal. In this study, the fatalities and non-fatalities events associated with rip current are $25(80.6 \%)$ and $6(19.6 \%)$, respectively, thus in an average year, approximately 2 people drown and died because of rip-related drowning incidents along Pahang coastline.

Table 3 shows the total number of drowning including death and rescue events for selected recreational beaches along the study area. The event number refers to the number of person that were drowned and rescued. The total number of drowning includes fatalities and non-fatalities, which are 24 . Almost $77.4 \%$ of the overall drowning data belong to the selected recreational beaches of $\mathrm{BA}, \mathrm{BH}, \mathrm{TC}, \mathrm{KEM}$ and SEP with TC showing the highest number of drowning cases.

For BA, the total drowning events included 7 fatalities and non-fatalities, which are equivalent to $29.2 \%$. Drowning cases that lead to death events are $4(57.1 \%)$ out of 7 and the rescue numbers are $3(42.9 \%)$. Both $\mathrm{BH}$ and $\mathrm{KEM}$ recorded no rescue and drowning death from years 2006 to 2018 . TC recorded 11 (35.5\%) drowning events with $8(72.7 \%)$ deaths and

\begin{tabular}{lccccrc}
\hline Beach section & BA & BH & TC & KEM & SEP & $\begin{array}{r}\text { that occurred on } \\
\text { selected recreational } \\
\text { beaches at Kuantan }\end{array}$ \\
Number of rescued & 3 & 0 & 3 & 0 & 1 & $\begin{array}{r}\text { coastline during the } \\
\text { period 2006-2018 }\end{array}$ \\
\hline
\end{tabular}

Table 3.

Statistics of drowning accidents that occurred on selected recreational coastline during the period 2006-2018 
EFCC

1,1

44

$3(27.3 \%)$ were rescued. For SEP, only one $(16.7 \%)$ rescue event and five $(83.3 \%)$ drowning to death were reported.

Most of the victims are seen carried by the current to seaward direction by the witnesses. In combination of panicking and inexperienced swimming skills, this hazard was believed the main cause that lead the increasing value of drowning with fatalities at BA, BH, TC, KEM and SEP within past 13 years.

\subsection{Morphodynamic beach state}

Figure 2 shows the $\Omega$ stations scatter plot for five recreational beaches along north Kuantan coastline. Due to the fact that samplings were very close in March and April for TC beach, the scatter plot seems to overlap with each other. Most of the $\Omega$ values are greater than 0.4 and less than 13, so most of the beaches are consider as intermediate beach state. Apart from that, this study also has reflective beach state and dissipative beach state.

According to our data, the north Kuantan coastline recreational beaches have potential rip current risk hazard especially in BA, BH, TC and SEP. A zoning mapping for rip currents hazard at north Kuantan coastline can be developed by connecting the drowning studies and morphodynamic studies, and the result shows the three out of five recreational beaches have potential rip currents especially in the north (BA and $\mathrm{BH}$ ) and south areas (SEP) of Kuantan coastline. TC beach can be considered as reflective-intermediate beach because of the morphodynamic state. As stated in Wright and Short (1984), Masselink and Short (1993), Short (1996), Saravanan et al. (2011), Scott et al. (2011) and Li (2016), rip current formations are dominated at intermediate beach state. Intermediate beach state classify when $\Omega$ is more than 1 and less than $6(1<\Omega<6)$. During this state, waves are depicted to be with more moderate to high energy, and the characteristic of sand is from fine to medium sand with longer wave periods.

To define morphodynamic beach state from quantitative view, both $\Omega$ and $\xi_{\mathrm{b}}$ were calculated for each survey and shown as in Table 4.

\section{Rip currents probability beaches}

Potential beaches for rip current occurrences are mainly located at north (BA and $\mathrm{BH}$ ) and south (SEP) Kuantan areas. One (TC) out of five recreational beaches may develop rip currents because of morphodynamical changes shown in Table 4. Example for rip current and non-rip current beaches are as follows.

Figure 2.

Scatter plot of the $\Omega$ station model result

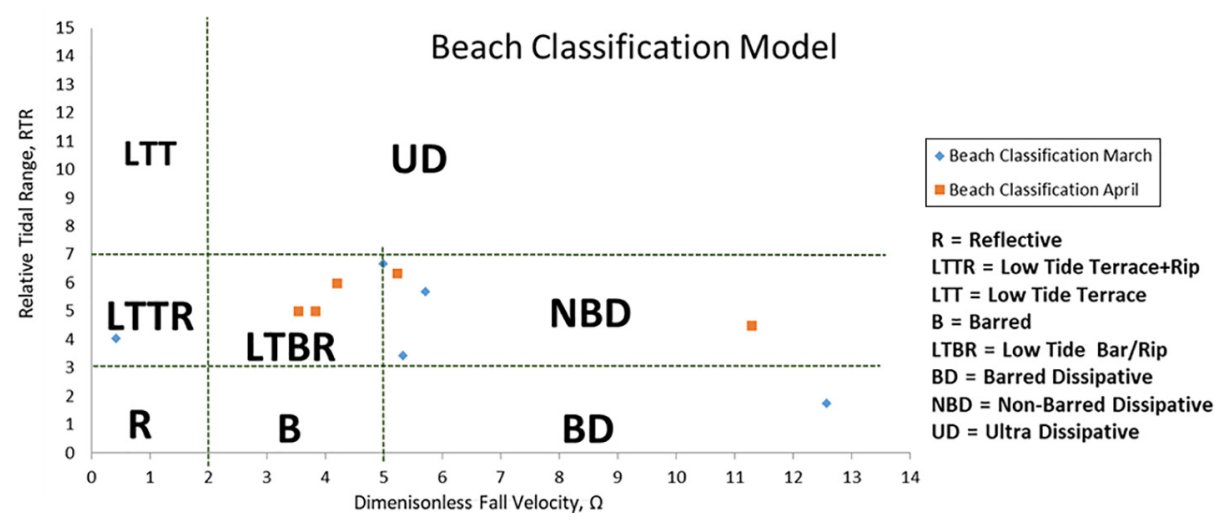




\begin{tabular}{|c|c|c|c|c|c|c|c|c|c|c|c|}
\hline $\begin{array}{l}\text { Study } \\
\text { area }\end{array}$ & $\begin{array}{c}\mathrm{D}_{50} \\
(\mathrm{~mm})\end{array}$ & $\begin{array}{l}\text { Mean } \\
\text { grain size }\end{array}$ & $\begin{array}{l}\mathrm{H}_{\mathrm{b}} \\
(\mathrm{m})\end{array}$ & $\begin{array}{l}\mathrm{T} \\
(\mathrm{s})\end{array}$ & $\begin{array}{l}\text { Tan } \beta \\
(\text { mean } \\
\tan \beta)\end{array}$ & $\begin{array}{l}\text { Surf similarity } \\
\left.\text { (mean } \xi_{\mathrm{b}}\right)\end{array}$ & $\begin{array}{l}\text { Breaker } \\
\text { type }\end{array}$ & $\Omega$ & RTR & Beach state & $\begin{array}{l}\text { Rip current } \\
\text { occurrence } \\
\text { probability }\end{array}$ \\
\hline \multicolumn{12}{|c|}{ (a) $M A R C H-14$} \\
\hline BA & 0.14 & Fine sand & 0.3 & 5.0 & 0.020 & 0.22 & Spilling & 5.71 & 5.67 & NBD & \\
\hline $\mathrm{BH}$ & 0.15 & Fine sand & 0.3 & 5.0 & 0.029 & 0.33 & Spilling & 5.00 & 6.67 & $\begin{array}{l}\text { LTBR and } \\
\text { NBD }\end{array}$ & 45 \\
\hline $\mathrm{TC}$ & 1.19 & $\begin{array}{l}\text { Coarse } \\
\text { sand }\end{array}$ & 0.5 & 9.2 & 0.092 & 1.49 & Plunging & 0.42 & 4 & LTTR & \\
\hline KEM & 0.17 & Fine sand & 1.1 & 5.8 & 0.032 & 0.22 & Spilling & 12.58 & 1.73 & $\mathrm{BD}$ & \\
\hline SEP & 0.16 & Fine sand & 0.5 & 7.2 & 0.033 & 0.43 & Plunging & 5.33 & 3.4 & NBD & \\
\hline \multicolumn{12}{|c|}{ (b) $A P R I L-24$} \\
\hline BA & 0.15 & Fine sand & 0.3 & 6.5 & 0.013 & 0.19 & Spilling & 3.83 & 5 & LTBR & \\
\hline $\mathrm{BH}$ & 0.16 & Fine sand & 0.3 & 6.5 & 0.027 & 0.24 & Spilling & 3.53 & 5 & LTBR & \\
\hline TC & 0.15 & Fine sand & 0.3 & 5.2 & 0.125 & 1.49 & Plunging & 5.22 & 6.33 & NBD & \\
\hline KEM & 0.15 & Fine sand & 0.4 & 3.2 & 0.045 & 0.29 & Spilling & 11.29 & 4.5 & NBD & Be \\
\hline SEP & 0.17 & Fine sand & 0.3 & 5.1 & 0.043 & 0.46 & Plunging & 4.19 & 6 & LTBR & $\begin{array}{r}\text { Bea } \\
\text { morphodynam }\end{array}$ \\
\hline \multicolumn{11}{|c|}{ Notes: (a) March; (b) April 2018} & D \\
\hline
\end{tabular}

\subsection{Balok}

BA is located about $15 \mathrm{~km}$ on the north of Kuantan, Pahang coastline Figure 1. Table 4 shows the $\Omega$ that indicates the morphodynamic of BA beach, dissipative beach state $(\Omega=5.71$ and RTR $=5.67)$, NBD beach type for the first month sampling campaign (March) and intermediate beach state $(\Omega=3.83$ and RTR $=5)$ low tide with bar/rip morphology beach type (LTBR) for second month sampling campaign (April). The $\xi_{\mathrm{b}}$ for both sampling is low because of spilling breaker, beach state and low beach gradient $(\tan \beta)$. During the low tide, sand bar and rip current topography are present at this beach that can be observed using aerial photo (Figure 3). This beach was believed to develop rip current hazards to swimmers, bathers or beachgoers during low tide.

\subsection{Batu Hitam}

$\mathrm{BH}$ is located about $10 \mathrm{~km}$ on the north of Kuantan coastline. The beach gets its name from unique black stone features at sandy shoreline at low tide area. The morphodynamic state of this beach is intermediate beach state for both samplings during March and April as $(\Omega=5$ and RTR $=6.67)$ and $(\Omega=3.53$ and RTR $=5)$, respectively. The beach type for BH morphodynamic for two sampling campaigns is low tide with bar/rip morphology (LTBR). Low value of $\xi_{\mathrm{b}}$ is because of spilling breaker and low beach gradient ( $\tan \beta$ ) shown in Table 4 . This beach may have potential to develop rip current hazard according to the structure of black stone that acts as a channel. This statement is in line with de Leon et al. (2008) who stated that the coral reef channel generated the rip currents instead of sand bar presence.

\subsection{Teluk Cempedak}

TC is located about $5 \mathrm{~km}$ east from town centre in Kuantan. The morphodynamic of TC beach is reflective with low tide terrace rip (LTTR) beach type $(\Omega=0.42$ and RTR $=4)$ and intermediate beach state, $\operatorname{NBD}(\Omega=5.22$ and RTR $=6.33)$ for March and April sampling campaign, respectively. The $\xi_{\mathrm{b}}$ for both months are low value because of the plunging 
EFCC

1,1

46

breaker and higher beach gradient $(\tan \beta$ ) that are believed to be the key factors that change the beach morphodynamic state. Even though the calculations for $\Omega$ and RTR does not indicate this beach as belonging to rip current beach, the drowning, near drowning data and beach morphology (beach cups) using drone as shown in Figure 4 still gives some information about potential that beach may develop rip currents.

\subsection{Sepat}

SEP is located about $10 \mathrm{~km}$ from Kuantan and the way south to royal town, Pekan. The morphodynamic state of SEP beach is seemed like more to dissipative with NBD beach type and intermediate beach state with low tide terrace bar/rip morphology beach type (LTBR)
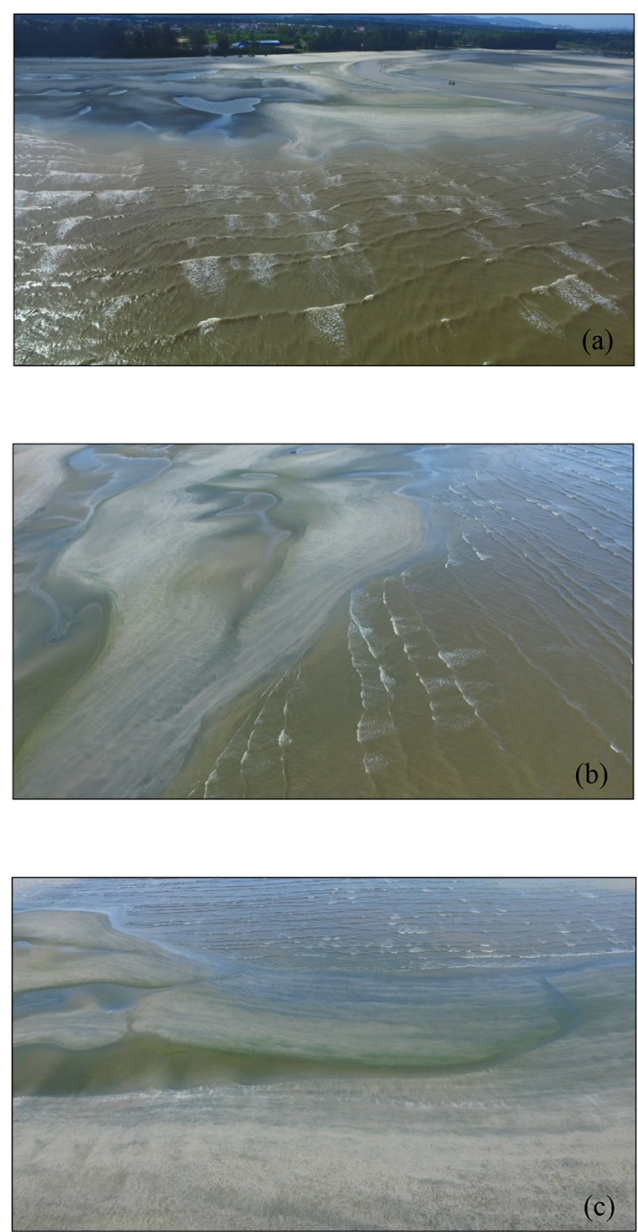

Figure 3.

Morphology of BA beach using drone
Notes: (a) Sand bar morphology along with rip channel; (b) sand bar at low tide level north view; (c) sand bar during low tide east view 

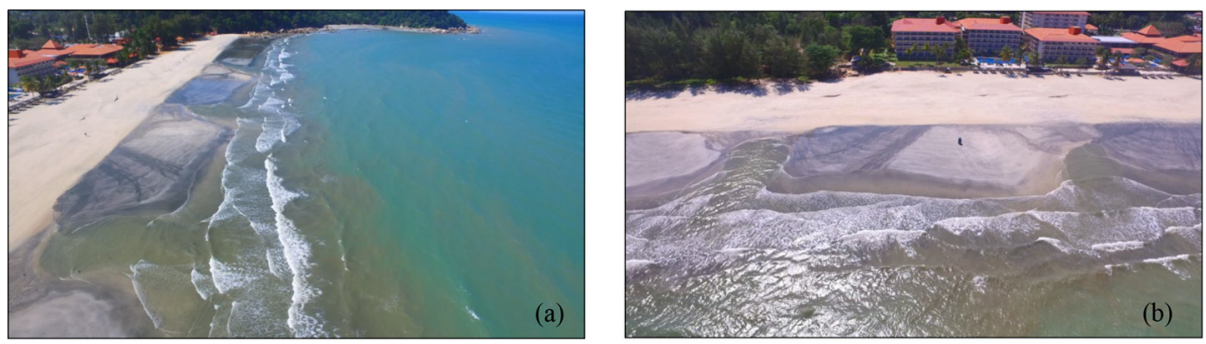

Rip current occurrence probability
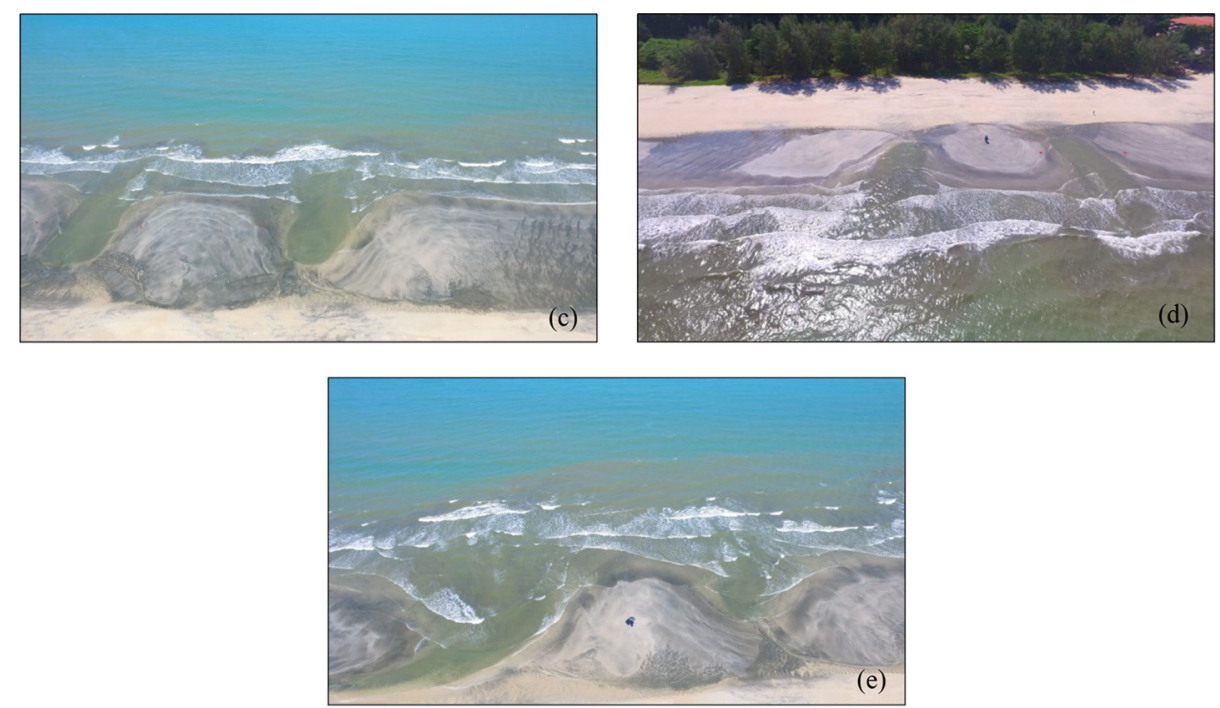

Notes: (a) Multiple beach cups at low tide level; (b) rip channel in front of the hotel landward view; (c) sand bar at low tide level seaward view; (d) more rip channel and sand bar landward view; (e) movement of current into rip channel

Figure 4. Morphology of TC beach

for two different months. The value for $\xi_{\mathrm{b}}$ at this beach is low for two months because of plunging breaker and beach state (low $\Omega$ reading). According to this study, this beach has potential to develop rip currents hazard accompanied by drowning cases of past 13 years.

\subsection{Non-rip current beach}

5.5.1 Kempadang. KEM is located at the south of Kuantan coastline. The morphodynamic state of KEM beach is dissipative beach state for two respective months. The $\xi_{\mathrm{b}}$ is second highest when compared to other beaches because of spilling breaker because this beach has high $\Omega$ readings. According to Jackson et al. (2005), the increasing in $H_{\mathrm{b}}$ will lead to an increasing value of $\Omega$. Therefore, the $H_{\mathrm{b}}$ values for KEM beach in both months are higher when compared to others. According to drowning report, this beach recorded zero drowning cases. Accompanied with this morphodynamic study, this beach does not show any rip current potential topography and sand bar formation for those two months study. 


\section{EFCC} 1,1

As stated earlier, TC beach state is inconsistent with reflective during March and intermediate during April. Possible reason is the changes of wave energy that are influenced by the monsoon exchange from northeast monsoon to inter-monsoon phase. During the northeast monsoon, the waves are stronger and more aggressive that would lead to higher erosional process. Comparisons are made for the two months data and results show that values of $\Omega$ and $\xi_{\mathrm{b}}$ are decreasing except for TC, KEM and SEP. As stated in Masselink and Pattiaratchi (2001), higher values of $H_{\mathrm{S}}$ and $\Omega$ indicate storm conditions (high wave energy) while lower values of $H_{\mathrm{s}}$ and $\Omega$ show calmer conditions.

\section{Conclusion}

Beaches are the most attractive destinations for tourist and for people world-wide. Rip current hazards have great impacts and challenges for beach management and safety. This study applied beach morphodynamic state that uses dimensionless fall velocity $\Omega$ model to estimate the preliminary rip currents beaches along Kuantan coastline. Results indicate four out of five recreational beaches have higher potential in developing rip current. These are the coastline areas covering from north (BA and BH), central (TC) and south (SEP). The results from this study demonstrate a consistent trend with field observation study as well as drowning incidents reported by media and newspapers. Beach model used in rip current prediction may be used for selection and beach management but it needs longer-term data observations and fieldwork for more accurate rip currents forecasting.

\section{References}

Alagesh, T.N. (2018), "Lain kali jangan degil", available at: www.hmetro.com.my/mutakhir/2018/06/ 349498/lain-kali-jangan-degil (accessed 27 July 2018).

Battjes, J.A. (1974), "Surf similarity", Proceedings of the 14th International Conference on Coastal Engineering, Copenhagen.

Berita Harian (2018), "Dua beradik lemas di pantai sungai balok", available at: www.bharian.com.my/ berita/kes/2018/08/460517/2-beradik-lemas-di-sungai-balok (accessed 25 August 2018), (in Malay).

Bernama (2014a), "Empat termasuk warga singapura lemas di Pahang”, available at: www.mstar.com. my/lokal/semasa/2014/04/21/empat-lemas-di-pahang (accessed 17 January 2018).

Bernama (2014b), "Pelajar UNITEN lemas Di teluk cempedak”, available at: www.mstar.com.my/lokal/ semasa/2014/08/02/penuntut-lemas (accessed 17 January 2018).

Blott, S.J. and Pye, K. (2001), "Gradistat: a grain size distribution and statistics package for the analysis of unconsolidated sediments”, Earth Surface Processes and Landforms, Vol. 26 No. 11, pp. 1237-1248.

Brighton, B., Sherker, S., Brander, R., Thompson, M. and Bradstreet, A. (2013), "Rip current related drowning deaths and rescues in Australia 2004-2011", Natural Hazards and Earth System Sciences, Vol. 13 No. 4, p. 1069.

Bruneau, N., Bonneton, P., Castelle, B. and Pedreos, R. (2011), "Modeling rip current circulations and vorticity in a high energy mesotidal-macrotidal environment", Journal of Geophysical Research, Vol. 116 No. C7, pp. 1-17.

Castella, B., Reniers, A. and MacMahan, J. (2013), "Numerical modelling of surfzone retention in rip current systems: on the impact of the surfzone sandbar morphology", Journal of Coastal Dynamic, pp. 295-304.

Castella, B., Marieu, V., Bujan, S., Splinter, K.D., Robinet, A., Senechel, N. and Ferreira, S. (2015), "Impact of the winter 2013-2014 series of severe Western Europe storms on a double-barred sandy coast: beach and dune erosion and megacusp embayments", Geomorphology, Vol. 238, pp. $135-148$. 
Cohen, O. (2016), "Profiler 3.2 XL: Mode d"employ", New Caledonia.

de Leon, M.P., Nishi, R., Kumasaka, F., Takaesu, T., Kitamura, R. and Otani, A. (2008), Reef Rip Current Generated by Tide and Wave during Summer Season: field Observation Conducted in Yoshiwara Coast, Ishigakijima, Okinawa.

Rip current occurrence probability

Dean, R. (1973), "Heuristic models of sand transport in the surf zone", Proceeding of engineering dynamics in the surf zone, Institution of Engineers, pp. 208-214.

Ferguson, R.I. and Chruch, M. (2004), "A simple universal equation for grain settling velocity", Journal of Sedimentary Research, Vol. 74 No. 6, pp. 933-937.

Galvin, C.J. (1968), "Breaker type classification on three laboratory beaches", Journal of Geophysical Research, Vol. 73 No. 12, pp. 3651-3659.

Gourlay, M. (1968), "Beach and dune erosion tests", Coastal Engineering, pp. 701-707.

Huntley, D.A. and Bowen, A.J. (1975), "Comparison of the hydrodynamics of steep and shallow beaches", in Hails, J. and Carr, A. (Eds), Nearshore Sediment Dynamics and Sedimentation, Wiley and Sons, London, pp. 69-109.

Jackson, D.W.T., Cooper, J.A.G. and Del Rio, L. (2005), "Geological control of beach morphodynamic state”, Marine Geology, Vol. 216 No. 4, pp. 297-314.

Kim, I.H., Lee, W.D., Shin, S., Kim, J.H., Hur, D.S. and Cho, W.C. (2016), "Study on rip current generated by submerged breakwaters: field observation and numerical simulation", Journal of Coastal Research, Vol. 75 No. sp1, pp. 1352-1356.

Kosmo (2012), "Bapa dan anak lelaki mati lemas di pantai sepat", available at: ww1.kosmo.com.my/ kosmo/content.asp? $\mathrm{y}=2012 \& \mathrm{dt}=0101 \& \mathrm{pub}=$ Kosmo\&sec=Terkini\&pg=bt_13.htm (accessed 17 January 2018).

Li, Z. (2016), "Rip current hazards in South China headland beaches", Ocean and Coastal Management, Vol. 121, pp. 23-32.

Loureiro, C., Ferreira, O. and Cooper, J.A.G. (2012), "Extreme erosion on high-energy embayed beaches: influence of megarips and storm grouping”, Geomorphology, Vol. 139-140, pp. 155-171.

Masselink, G. and Pattiaratchi, C.B. (2001), "Seasonal changes in beach morphology along the sheltered coastline of Perth", Marine Geology, Vol. 172 Nos 3/4, pp. 243-263.

Masselink, G. and Short, A.D. (1993), "The effect of tide range on beach morphodynamics, a conceptual model", Journal of Coastal Research, Vol. 9, pp. 785-e800.

Mustapa, M.Z., Saad, S., Abdul Hadi, M.S., Yunus, K. and Sapon, N. (2015), "Beach-face morphodynamics of different morphological setting along Teluk Chempedak to Kuala Lumpur, Malaysia”, Jurnal Teknologi, Vol. 77 No. 25, pp. 51-56.

N.A (2014), "Ketua pemuda Pahang ziarah keluarga mangsa lemas", available at: https://pahangnews. wordpress.com/2014/09/16/ketua-pemuda-pahang-iarah-keluarga-mangsa-lemas/ (accessed 17 January 2018).

N.A (2017), "Pekerja kilang dikhuatiri lemas di cherating", available at: https://peraktoday.com.my/ 2017/01/pekerja-kilang-dikhuatiri-lemas-di-cherating/ (accessed 17 January 2018).

Rosnan, Y. and Zaini, M.M. (2010), "Grain-size distribution and subsurface mapping at the Setiu wetlands, Setiu, Terengganu”, Environ Earth Sci, No. 60, pp. 975-984, doi: 10.1007/s12665-0090236-9.

Saravanan, S., Chandrasekar, N., Sheik Mujabar, P. and Hentry, C. (2011), "An overview of beach morphodynamic classification along the beaches between Ovari and Kanyakumari, Southern Tamil Nadu Coast, India”, Physical Oceanography, Vol. 21 No. 2.

Scott, T.M., Masselink, M.J. and Rusell, P. (2014), "Controls on macrotidal rip current circulation and hazard”, Geomorphology, Vol. 214, pp. 198-215.

Scott, T., Masselink, G. and Rusell, P. (2011), "Morphodynamic characteristic and classification of beaches in England and Wales", Marine Geology, Vol. 286 Nos 1/4, pp. 1-20. 
EFCC

1,1

Shepard, F.P. (1936), “Undertow, rip tide or 'rip current”, Science, Vol. 84 No. 2173, pp. 181-182.

Short, A.D. and Hogan, C.L. (1994), "Rip current and beach hazard: their impact on public safety and implication for coastal management”, Journal of Coastal Research Special Issues, Vol. 12, pp. 179-209.

Short, A.D. (1996), "The role of wave height, period, slope, tide range and embaymentisation in beach classification: a review", Revista Chilena de Historia Natural, Vol. 69, pp. 589-604.

Tukimat, N.N.A., Othman, A.S., Wan Ahmad, S. and Muthusamy, K. (2018), "Evaluation of climate variability performance using statistical climate models", Sains Malaysiana, Vol. 47 No. 1, pp. 77-84.

Utusan Malaysia (2006), "Tiga sahabat karib mati lemas", available at: ww1.utusan.com.my/utusan/ info.asp? $\mathrm{y}=2006 \& \mathrm{dt}=0131 \& \mathrm{pub}=$ Utusan_Malaysia\&sec $=$ Dalam_Negeri\&pg $=$ dn_04.htm (accessed 17 January 2018).

Utusan Malaysia (2009), "Lagi korban lemas Di pantai cherating”, available at: www.utusan.com.my/ berita/wilayah/pahang/lagi-korban-lemas-di-pantai-cherating-1.234017 (accessed 17 January 2018).

Utusan Malaysia (2012a), "Pantai sepat ragut nyawa lagi", available at: ww1.utusan.com.my/utusan/ info.asp? $y=2012 \& d t=0123 \&$ pub=Utusan_Malaysia\&sec=Terkini\&pg=bt_32.htm (accessed 17 January 2018).

Utusan Malaysia (2012b), "Dua beradik lemas ketika mandi Di pantai sepat”, available at: ww1.utusan. com.my/utusan/info.asp?y=2012\&dt=0122\&pub=Utusan_Malaysia\&sec=Terkini\&pg=bt_22. $\mathrm{htm}$ (accessed 17 January 2018).

Wright, L. and Short, A. (1984), "Morphodynamic variability of surf zones and beaches: a synthesis", Marine Geology, Vol. 56 Nos 1/4, pp. 93-118.

\section{Further reading}

Righton, B., Sherker, S., Brander, R., Thompson, M. and Bradstreet, A. (2013), "Rip current related drowning deaths and rescues in Australia 2004-2011”, Natural Hazards and Earth System Sciences, Vol. 13 No. 4, pp. 1069-1075, doi: 10.5194/nhess-13-1069-2013.

\section{Corresponding author}

Muhammad Zahir Ramli can be contacted at: mzbr@iium.edu.my

For instructions on how to order reprints of this article, please visit our website: 